\title{
Impacts of Demonetization in the Indian State Arunachal Pradesh: A Political Gimmick or Robust Policy
}

\author{
Sandeep Kumar Gupta, Serdar Vural UYGUN, Sandeep Sharma, Santosh Kumar Yadav, \\ Laodiceia Amorim, Weersma Svetalana Ilinich
}

\begin{abstract}
On November 8th, 2016, the Indian Government announced the demonetisation of the 500-rupee and 1000-rupee currency notes. Demonetisation is the process in which particular notes or coins are withdrawn from the circulation as a legal tender. The main objectives of demonetisation are, in general, to control corruption, black money, the finance of terrorist organisations and the duplicity of currency notes within a country. In the case of India, the 500-rupee and 1000 rupee notes ceased to be a legal tender starting from December 31st, 2016, and people having this demonetised currency notes had to change them or deposit them into their bank accounts. The objective of this research paper is to highlight the impacts that demonetisation brought to India.
\end{abstract}

Index Terms - Demonetization, Black money, Terrorist organisation, Digital India, Public policy, Direct taxes, Indirect taxes

\section{INTRODUCTION}

The process of withdrawing currency from its circulation is known as Demonetization. The recent demonetization took place on November 08, 2016 by the announcement of the present Indian government. In this recent demonetization, the government bands the currency note of INR 500 and 1000. In the past also demonetization took place in India in January 1946 and again in 1978. The highest demonetization note had printed by reserve bank of India. The currency was the paper currency of INR 10000 in 1938 and again in 1954 . However, these currencies were demonetised in January 1946 and 1978 respectively.

The present demonetization of INR 500 and INR 1000 was introduced in India on 8th Nov 2016 by Indian government to control the corruption, black money, funding to terrorist organisation and duplicity of currency notes. In the place of old INR. Five hundred currency notes the government and RBI decided to introduce the new 500 and 200 currency notes

Revised Version Manuscript Received on April 12, 2019.

Sandeep Kumar Gupta, Sharda University, Greater Noida, India (E-Mail: skguptabhu@gmail.com)

Serdar Vural UYGUN, Nevsehir University, Nevsehir, Turkey (E-Mail: svuygun01@gmail.com)

Sandeep Sharma, Department of Mathematics, DIT University, Dehradun, India (E-Mail:sampark81@gmail.com)

Santosh Kumar Yadav, Department of Commerce and Management, Indira Gandhi Technological and Medical Sciences University, Zero, Arunachal Pradesh, India

(E-mail: santosh217976yadav@gmail.com)

Laodiceia Amorim, Professor of Entrepreneurship and Innovation, Cetro Universitario Christus, Brazil (E-mail: laoweersma@gmail.com)

Weersma Svetalana Ilinich, Professor of Social Inclusion, Open International University of Human Development, Vinnytsia, Ukraine, (E-mail: ilinichsvitala@ukr.net) with few additional security features.

\section{HISTORICAL BACKGROUND}

Demonetization has been introduced in many other countries all over the world, for example in Ghana in 1982, Nigeria in 1984, Myanmar in 1987, Zaire in 1990, the USSR in 1991, and North Korea in 2010.

In the case of India, firstly it was successfully introduced changes in currency note twice in the past, in 1946 and 1978. In 1946, the paper currency of INR 1,000 and INR 10,000 had removed from active currency market. The ban did not have much shock, as the higher value of currency denomination was not reachable to ordinary people.

However, both the currency had reintroduced in 1954 with an further introduction of INR 5,000 currency, INR. 500 and INR.1,000 notes had introduced in 1934, and after four years in 1938, INR 10,000 notes had introduced. In 1978, Indian government had decided to drive away Un-audited funds out of circulation of the Indian economy.

However, the high demonetization bank notes (demonetization) act had imposed for the third time in the Indian history on November 08, 2016. Therefore, the government of India announced a band on the currency notes of Rupees 500 and 1000 from the circulation and announced the introduction of new paper currency.

Demonetization had initiated with a broad scope of motives, and this research study has following objectives with a core focus to find out the real shock of demonetization in India and especially in Arunachal Pradesh:

- To stop the funding to the terrorist organisation and curbing them

- To stop the circulation of black money in India

- To stop the duplicity of the currency notes promoted by neighbour countries

- To minimise the use of paper currency

- To increase the taxes revenue

- To promote the digital India movement

- To promote development honest public policy implementation for economy 


\section{IMPACTS OF DEMONETISATION IN THE INDIAN STATE ARUNACHAL PRADESH: A POLITICAL GIMMICK OR ROBUST POLICY}

\section{IMPACT OF DEMONETIZATION}

On Personal Finance and Digitalization: It has been observed all over the world that People finally began to trust on the electronic payment system because that was the only payment option was available. Penny Bank, Vault or Depository has been transformed into Savings Accounts instead of keeping emergency cash.

However, the use of digital payment system proved fruitful only to MNC's, and people residing in cities, whereas in backward areas and remote area, digital payment system failed due to lack of knowledge, technology and infrastructure as Arunachal Pradesh is one of the Northeastern of states India. Furthermore, the state situated in a hilly areas and challenging geographical location.

Therefore due to shortage of bank branches, insufficiency infrastructure and technology, people faced adversity in depositing their cash in the Banks. However, the circulation of cash in the economy initiate to increase; digitalisation saw a slide once again.

On Black Money and Corruption: People supported demonetization because of its association with bringing a remove the black money and corruption. However, almost $99 \%$ of the paper currency of 500 and 1000 was received back to RBI, and it had revealed that hoarders found a way to legitimise their black money.

On Terror Funding and Duplicity of Notes: People also supported demonetization because of its role in curbing Terrorism and the use of fake currency notes. The direct tax department seized INR 4074.37 million in new and old paper currency of 500 and 1000 from November 2016 to January 2017. However, there are no statements if the money seized of any organisation for terror funding. However, no doubt for a short period, the duplicity became controlled.

On Tax Payments: Demonetization affected the majority of people to pay their taxes and increase the tax bracket network. Government sources report the income taxpayers saw a significant growth in the post demonetization era, 9.1 million new taxpayers had added to the tax slab which was an $80 \%$ rise over the classic yearly rise.

Elections: In India when the demonetization take place just after that the election of five states were scheduled. The political parties had not prepared for such type of change in the country. The raid was happening so that the political parties could not focus on elections.

Gold, Silver and Jewelry: After the demonetization, the demand for Gold, Silver and Jewelry became very high and all the black money holders were swapping their black money into jewellery and other valuables.

GDP: Demonetization had mentioned as one of the key grantor to the slowdown of economic growth. The GDP of the nation decreased by about $2 \%$, and the slowdown has cited. As a result, a repercussion of demonetization by the World Bank and there are various other reasons at play, the steep decline has been credited to be an outcome of demonetization

On MSME's: Demonetization had a lasting outcome on Indians Small and Medium Enterprises (SMEs). Various SMEs turned towards digitalisation. However, among their small counterparts, the micro industries were poorly realized.

The micro and tiny industry owners were not a part of the black economy, and they were not unable to manage the outcome of demonetization.

\section{FINANCIAL EXPRESS REPORT ON DEMONETIZATION IMPACTS:}

Arunachal Pradesh Villagers adopt unique method- during the time of credit crunch, rural areas in Arunachal Pradesh suffered severely. Villages such as Chinghan, Horu Chinghan, Konyu, Konsa, Noglo, Nisa, Changkhao, Hongkong on the Myanmar Border in Arunachal Pradesh were unaffected by the government of India historic decision to demonetise INR 500, INR1000 notes. This area still went through with conventional barter system techniques to run their domestic economic system. On an initiative ordered by state government, the district authorities formulated a currency disbursement van, and the local SBI Branch has started serving people exchange their old notes. However, other areas in the northeast have experienced many difficulties. For example, in Anjaw District has only one branch of SBI, located at Hawai. People have been facing unthinkable adversity because even after travelling up to 100 $\mathrm{km}$ on shared taxis. The government was unable to provide and maintain swap services because of lack of administrative staff and unavailability of cash.

\section{A SUICIDE OF BANK OFFICIALS IN ARUNACHAL PRADESH \& RESULTS}

The suicide of a branch manager of HDFC bank in Arunachal Pradesh branch due to "monetary issues" has drawn notice to the illegal transactions, conversion of un-auditable money into white that have allegedly taken place in the north-eastern state after demonetization came into effect.

The suicide came to important matter soon after reports emerged that large amounts of cash had transferred into the north-eastern states for illegal notes accepted for swap in another small note. According to local news sources of websites. Head of Naharlagun (Ita Nagar) branch of HDFC bank, committed suicide by himself on 21 December 2016 in his rented house. The SDPO of Naharlagun, has given information. The Arunachal Times sources that the deceased left a self-slaughter note, where he mentioned about monetary issues. He added that the note had sent for forensic test. The report said that the top officials of the HDFC bank have also reached Naharlagun to investigate the matter. Though there has been no government statement on what the "financial matters" were, Asomiya Pratidin, local daily news in Assam reported that the currency refers to an associated with cash scam. The official report mentioned unlawful transactions of INR 1,300 crores in unaudited sources and said that the HDFC bank official was facing an inquisition for being allegedly involved in it.

Deccan Chronicle sources told that a considerable amount of fund had smuggled into Arunachal Pradesh post-demonetization and bank officials was under pressure from various inquiries to explain cash the transactions. 
The report further officials said that INR 1,300 crores had deposited in a dummy bank account, and that manager had mentioned the names of a few contractors and politicians in his suicide note, who had allegedly deposited vast amounts of demonetised notes in his branch. The Deccan Chronicle official sources said that cash belonging to local politicians from neighbour state was routed to Arunachal Pradesh after 8 November 2016. The North-east, Arunachal Pradesh is one among them, have recently come under the radar because of unknown sources conversion due to the direct tax exemption status of Arunachal Pradesh. According to The Indian Express, a month ago state government had asked the direct tax department to trace all fake bank accounts that "abnormal from normal history and nature of deposit and take proper actions".

The Indian Express news quoted, state government statement, "Since frauds are likely to take place on accounts of tribes exempted from direct taxes, there is a possibility of some people from outside the state trying to use HDFC bank accounts of native tribes deposited in huge money". The state government came to know just after a report emerged that native people, a people of Nagaland had arrested for allegedly attempting to swap of demonetised notes belonging to a north India based business person.

In 2012, the direct tax department had issued circular concerns that local tribes, who are not tribes of the North East, are availing benefits of direct tax exemption granted to the Scheduled Tribes of the region. As per the official report, only income earned in the specified region is subject to direct tax exemption. The complication, however, turned severe after demonetization; with reports emerging of cash being deposited from other parts of the country in the in their bank accounts of tribal's for illegal notes swap. Even terrorist groups in the area were reported to have tackle to deposit cash in the accounts of the local tribe's.

Police Chief of South Garo Hills District in Meghalaya, said that First-post that terror money worth a crores had recovered while being deposited in the bank accounts of residents. A direct tax official told to First-post, on condition of invisibility, that there is a common misconception that cash deposited in the bank accounts of the tribes of the area will not be disclosed in their accounts. "This is not correct as these activities can also to be subjected to scrutiny," the source said.

\section{CONCLUSION}

The government of India has decided demonetization to fulfil specific objectives like, for example, to stop the circulation of black money, the duplicity of the currency note, illegal funding. According to sources, currency worth Rs. 15.41 lakh crores were banned, and the RBI has found that Rs. 15.30 (99.3\%) lakhs crores have returned as on June 30, 2017. The banknotes that had not deposited were only worth Rs 10720 crores.

Such reports confirm the damning failure and a vast difference would have given the government an estimate of black money. However, the report addresses it clear that there is no significant black money 'in cash' in India or that black money holders made their illegal income legal by exchanging them at bank counters either directly or indirectly.

Experts say that the government can still claim success because now the black money holders face the risk of getting caught by the direct tax department. During the year normal growth showed across the word 1\% of GDP, but in India, It was 1.5\% -2\%,(2016-17 INR 8.5 lakh crores .2017-18 INR 10.02 lakh crores and 2018-19, it is expected INR 12 lakh crores. In indirect taxes: GST 18\% growth every year and it has expected INR 7.61 lakh crores and INR 15278 crores duplication catch by a department in 8 months during the current financial year.

In India, 92\% cash transaction, it is highest in the world, which increases the cash handling cost of paper currency in every two years of paper currency uses. Demonetization has increased significant deposits and taxpayer bases in India; it is transparent financial inclusion and minimises financial corruption without affecting rural India agriculture system.

As per our perception, the decision was unplanned and without any homework because the lending authority has failed to remove black money from the economy. Till yet top authority is unable to find significant sources of deposited money unusually in November - December 2018 the GDP of the nation decreased by about $2 \%$. Hence it was unsuccessful and caused an unnecessary additional burden on the Nation's economy.

Furthermore, it has become a significant tool to stop fake currency supported by a corrupt local politician and terrorist groups for stopping their anti-nation activities, minimize the use of paper currency, motivate the people to pay their tax liability and using more electronic mode of payment, which is giving more source of income to prepare healthy public policy and improve the living standard of people.

Ethics: We do not have any requirement for permission for review findings.

Competing Interests: we have no competing interests.

Funding: We do not take any funds from any sources.

\section{REFERENCES}

1. Singh, A. (2017). Impact of demonetization on Indian economy. International Journal of Engineering and Management Research (IJEMR), 7(3), 785-788.

2. Ganesan, G., \& Gajendra Nayagam, B. (2017). Impact of demonetization on Indian Economy. International Journal of Applied Research, 3(9), 433-436.

3. Shah, A. Y. (2017). Impact of Demonetization on Rural India. International Journal of Scientific and Research Publications, 7(3), 220-223.

4. Shirley, M. A. J. (2017). Impact of demonetization in India International Journal of Trend in Research and Development, 20-23.

5. 5 .

www.facebook.com/IndiaUnravelled2019/videos/23447558724 11348/

6. Singh Prabhsimaran, Sawhney R.S.\& Kahlon K.S.(2018) Sentiment Analysis of Demonetisation of $500 \& 1000$ rupees bank notes by Indian Government.ScienceDirect Volume 4, Issue 3, September

7. Zhu Heng, Gupta Abhinav, Majumdar Binoy \& Steinbach (2018) Short term effects of India's demonetisation on Rural People. Economics Letters, Elsevier, Volume 170, September, 117-121.

8. Financial Express, dated: Nov 15th, 2016

9. First Post, dated: Dec 27th, 2016

10. Business Standard: Dec 27th 2016

11. Amar Ujala Business February 18th 2019 